\title{
Women's Participation and Representation in Nigerian Politics: Observations from the 2015 General Elections
}

\author{
Oluwatooni Akinkuotu* \\ Research and Studies Department, Nigerian Institute of International Affairs, \\ 13/15 Koko Abayomi Street, Victoria Island, Lagos, Nigeria \\ Osita Agbu Ph.D \\ Department of International Relations and Diplomacy \\ Faculty of Social and Management Sciences, Baze University \\ Plot 686 Cadastral Zone C00, Kuchigoro, Abuja, Nigeria
}

\begin{abstract}
The paper investigates the conceptual and material bases of women's exclusion from the formal arena in politics. It discusses the structural barriers within formal institutions, strategies to promote women's political participation and representation adopted around the world, and identifies internal and external conditions that have both facilitated and hindered women's political empowerment in Nigeria. Despite their numbers, politics remain an area in public life solely dominated by men. Faced with structural and financial barriers, the paper argues that there is a deeper need to change attitudes and relationships at many levels, including making women's as well as men's interests integral to the design of programmes in all political, spheres.
\end{abstract}

Keywords: Women in politics. Political parties. Elections. Sustainable development. Political participation. Political representation.

DOI: $10.7176 / \mathrm{JAAS} / 53-03$

Publication date:March $31^{\text {st }} 2019$

\section{Introduction}

Over the past two decades, efforts to create equal opportunities for women in Nigeria to participate in politics and to increase female representation in government leadership continues to be a major challenge. Although government's commitment to the implementation of international principles and provisions have been reasonable, Nigeria still falls far behind both global and continental representational and participatory milestones. Nigeria's challenge of under-representation of women in politics and decision-making is deeper than the usual rhetoric that "there are no suitable women" to fill political vacancies or take up political appointments. The exclusion of women from leadership and decision making it is argued is reinforced by the patriarchal structure of the Nigerian society, which does not create a level playing field on which both men and women can equally compete. The constitution of the Federal Republic of Nigeria is clear in its provision against discrimination of persons on grounds of gender. This has also guided the government's international actions. For this reason, issues of gender imbalance are not only regulated by both national and international norms, but are also governed by democratic practices that administer equality.

One of the key concerns surrounding the 2015 general elections and the subsequent formation of the Muhammadu Buhari government was the role women played and would play in the political and decision making process. Such concerns were multiplied by Nigeria's poor commitment to reducing the gender gap in political participation and in decision making positions, whether in elected office, the civil service, the private sector or academia. The reality is that such concerns have been mirrored by civil society groups and NGOs that over the years have monitored the government's commitment to international provisions and principles of gender equality. Nigeria in general has a huge gender problem. The gap between men and women is present not only in political and public life, but on issues of nationality, education, employment, access to health care, social and economic rights, before the Law, as well as in marriage and family life. This is worrying for a country that recognises and has committed itself to international conventions on eliminating all forms of discrimination and violence against women. Given that gender differences in participation could reproduce gender inequalities in other domains, understanding this participatory inequality is central to the design of this paper.

Two key questions informed the focus of this paper: What perpetuates the political exclusion of women from national political process? And how to break the cycle of marginalisation? Simply put, this is a study on discrimination and inequality in Nigerian politics, with particular attention given to what the outcome of the 2015 general elections tell us about women's role in politics. This paper investigates the conceptual and material bases of women's exclusion from the formal arena of politics. It analyses the structural barriers within formal institutions, strategies adopted around the world to promote women's political participation and representation, and identifies internal and external conditions and factors that facilitate or hinder the creation of an enabling environment for women's political empowerment in Nigeria. It concludes by offering recommendations for 
national and international actors.

\section{From Theory to Action: The Role of International Actors and Transnational Influences}

As the wave of democratisation swept across the world, from Eastern Europe to Sub-Saharan Africa, scholars began to explore what led to the process of democratisation and how transition affected citizens. Within this scholarship, studies addressing women and democracy rose to the fore. Yet most studies in this area focused more on Eastern Europe and Latin America, leaving a gap in the study on sub-Saharan Africa. Although progress is being made in the collection of data, data quality issues continue to be a challenge as some areas completely lack information such as the internal workings of most political parties in Africa. However, recent data collection efforts on both political participation and representation levels have accomplished three key goals. Firstly, it has enabled more rigorous analysis into the gender gap within contemporary democratic process. Secondly, it has created space for gender equality to emerge as an important goal in democratic processes such as electoral processes and constitutional reform processes. Finally, it has shaped and expanded the understanding of human rights theory to acquire women's rights within the universal human rights bill.

The concepts of discrimination and equity in the study of political science or gender studies are extremely misleadingly simply because they mean different things to different people. Even within the context of political representation, the literature on gender gap in politics is broad as well as it is diverse, addressing gender differences in political acts and political knowledge; social relationships, interactions and attitudes; and women's place in political theory. Despite the availability of broad definitions of these contested concepts, the international community has come together on several occasions to acknowledge the importance of political representation as a tool to strengthen democratic governance and limit various forms of gender discrimination. As the 2011 United Nations (UN) General Assembly resolution on women's political participation notes,

"Women in every part of the world continue to be largely marginalized from the political sphere, often as a result of discriminatory laws, practices, attitudes and gender stereotypes, low levels of education, lack of access to health care and the disproportionate effect of poverty on women." (UN Women)

In 1979, the UN General Assembly adopted the Convention on the Elimination of All Forms of Discrimination against Women (CEDAW), consisting of 30 articles that define what constitutes discrimination against women and sets up an agenda for national action to end such discrimination. The Convention provides the basis for realizing equality between women and men through ensuring women's equal access to, and equal opportunities in, political and public life. Article 7 specifically speaks to such opportunities and recognises women's political status for the achievement of both a transparent and accountable government. It also provides the foundation for gender equality in public life by affirming women's rights to vote and to stand for election; to participate in the formulation and implementation of government policy; and of freedom of association.

In addition to focusing on issues of discrimination, there was also a strong focus on the equity dimension, looking at the power relations that prevent women from living fulfilling lives. These restrictions were seen to operate at many levels of society, from the most personal to the highly public. Thus achieving the goal of equal participation of women and men in decision-making is believed to provide a balance that reflects the composition of an open society and also needed in order to strengthen democratic practises. For this reason, in 1995, UN Member State gathered at the Fourth World Conference on Women in Beijing, China, and adopted a plan of action for equality, development and peace. The actions to be taken on equity in political decisionmaking included measures to ensure women's equal access to and full participation in power structures and decision-making, and to increase women's capacity to participate in decision-making and leadership. The Member States recognised that without leveraging on equality in political decision-making, real integration of the equality dimension in government policy-making would not be feasible. To which end, women's equal participation in political life was seen as a pivotal part in the general process of the advancement of women.

\subsection{Achieving Milestones at the International Level}

The role of international actors and transnational influences in furthering women's political rights and representation has helped to intensify efforts in Nigeria. On discrimination against women, pressure from the United Nations and Women's International Nongovernmental Organizations (WINGOs), have shown to not only influence women's suffrage as well as encourage gender mainstreaming policies, but enriched global debate. Part of the milestones achieved at the global level in the quest to redress gender imbalance in politics began with the international recognition of the several obstacles women have, and still continue to face in political life. The main challenge being how to redress gender inequalities in societies with already strong norms and traditions, by enhancing participation in governance structures. The Beijing Declaration and Platform of Action; the outcome of the twenty-third special session of the General Assembly titled 'Women 2000: Gender equity, development and peace for the twenty-first century'; the Convention on the Elimination of All Forms of Discrimination against Women; UN Economic and Social Council resolution 1990/15; and the Resolution adopted by the 
General Assembly on 19 December 2011, all affirmed the obligation of all States to protect human rights and equity of women around the world. Countries that signed these international treaties, according to studies carried out by Gray (2006), Kenworthy and Malami (1999) are more likely to have more women in political office or relatively high numbers of women in national legislatures. Further research has shown that International Nongovernmental Organisation (INGOs) are able to persuade influential persons in government, hold nations accountable to the international treaties they ratified, and increase domestic awareness of women's plight in politics (Keck ME, 1998). Such is the case with the Nigerian NGO CEDAW Coalition, conceived as an interventionist strategy and response to the proposed inaccuracies reported by the Nigerian Government in its second and third periodic country report to UN CEDAW Committee.

These international commitments have galvanized international efforts for the advancement of women in political and public life. The global commitment to redress all forms of discrimination including gender imbalances in politics are stipulated in CEDAW. These commitments are reinforced from with the Nairobi Forward Looking Strategies on the Advancement of Women, to the 1995 Beijing Platform of Action, and even in the 2000 UN Millennium Development Goals (Goal 3). The MDGs measured progress towards gender equality in part by the proportion of women holding parliamentary seats. The MDG 2013 Report noted that the proportion of seats held by women in single or lower houses of national parliaments in sub-Saharan Africa increased by only 8 per cent between 2000 and 2013, from 13 per cent to 21 per cent (Tsododo, 2014). Towards Goal 3, the UN provided training for women political candidates to help build capacities, and offered civic education as well as sensitisation campaigns on gender equality. Support was also given to gender equality advocates by calling on political parties, governments and civil society organisation and associations to play a bigger role in empowering women. Other initiatives encourage young men and women to engage in advocacy around making gender equality measures central to public policymaking (UN Women).

\subsection{Achieving Milestones at the Continental Level}

Today the UN Sustainable Development Goals and related targets to replace the MDGs contain concrete points about how to empower women. In addition to the specific goal of attaining gender equality and empowering women and girls globally, there is another goal that refers to strengthened and enhanced means of implementation for all SDGs. Under this heading, the goals proposed practical and measurable delivery mechanisms such as achieving universal access to ICT for both sexes by 2030 as well as a means to empower women. A significant shift from the MDGs which were criticised for proffering unmeasurable goals such as 'women empowerment', which in relative terms proved difficult to monitor.

Since the 1985 adoption of the Nairobi Forward Looking Strategies on the Advancement of Women, gender equality and women's political participation and representation at all levels has become a prominent part of politics in Africa and the rest of the world. In 2003, the African Union adopted the Protocol to the African Charter on Human and People's Rights on the Rights of Women in Africa which also asserts women's rights to enjoy social and political equality with men among other rights in all spheres of life (Kandawasvika-Nhundu, 2013). Many international conferences have agreed to a target of 30 per cent representation of women in decision-making positions in government and the private sector. In Africa, only 11 countries had met this target as of April 1, 2014, and only Rwanda had more women than men in Parliament, with 63 per cent (a global achievement as well as a national success).

At the regional level, the Southern African Development Community (SADC) Protocol on Gender and Development (2008) called for 50 per cent representation of women in decision-making positions in both public and private sectors by 2015 (Tsododo, 2014). However, only four SADC countries have met the 30 per cent threshold, and no SADC state has met the SADC protocol recommendations. The Economic Community for West African States (ECOWAS) has made progress since the recognition of twelve critical areas of concern of the Beijing Platform of Action. In addition to the development of a gender and development centre and a Regional Gender Policy Framework as well as a Gender Management System, ECOWAS has initiated many programmes through the Centre in health, education, economic empowerment and technical support that target women. The Centre has put together training exercises and workshops on gender analysis and integration for the ECOWAS Commission directors; and on sensitizing ECOWAS parliament representatives on gender and advocacy; and on women's leadership.

\subsection{Representation in Political and Public Life}

Nigeria remains predominantly a patriarchal society in which cultural norms and religious institutions significantly influence the moulding of gender identities. Despite the leading movement towards democratisation in Africa, women are largely underrepresented at most levels of government, particularly in ministerial and other executive bodies, and have made little progress in attaining political power in legislative bodies or in achieving the target endorsed by the Economic and Social Council of having 30 per cent women in positions at decisionmaking levels by 1995 (The United Nations Fourth Conference on Women, 1995). Moreover, many schools of 
thought exist with equally different ideas on the expectations for male and female behaviour which continues to contribute to women's continued underrepresentation in political leadership roles and hinders any significant progress in terms of women's access to power (Tsododo, 2014). Two major colonial policies helped to promote partriachism in the politics that is practised today in Nigeria. The first being the colonial perception that only men can be active in the public sphere (Awofeso \& Odeyemi, 2014). The second was limited access to education. Awofeso and Odeyemi (2014) pointed out that educational assistance programmes when made available under the colonial administration were reserved for only males who were later recruited into the colonial civil service and merchant houses. This practice gave Nigerian men an undue advantage and experience, marking the start of institutionalised marginalisation of women from public life.

Although a lot has changed since then, the trend in terms of women's access to power in recent decades has been one of gradual but steady progress ever since international recognition of the challenges women in Nigeria face was achieved. In 1985, the government ratified the CEDAW without reservations, consequently binding itself to put all obligations stated in Article 2, towards the promotion of the principles of CEDAW and other internationally agreed norms and standards relate to women's leadership and political participation, into practice. The government is also committed to submitting national reports, at least every four years, on measures it has taken to comply with the treaty obligations.

Since the return to democracy, not only has the global perception and the importance of gender equity increased, Nigeria continues to demonstrate and reaffirm her commitment to the implementation of the principle and provisions of the CEDAW, the Beijing Declaration and Platform for Action (BPfA), the Outcome of the 23rd Special Session of the General Assembly, the MDGs (SDGs) and other international commitments to achieve gender equality. To date, the government has submitted eight national reports on measures it has taken to comply with CEDAW. The national reports reveal the measures undertaken by the government from 1999, to fulfil its obligations under the Convention, including steps taken to address the participation of women in political and public life. Since the development of the Nigeria 6th, 7th and 8th CEDAW report (covering the period 2003 to 2014), the Federal Government has made system wide efforts to generate inputs from within government MDAs and its State counterparts, CSOs and development partners. The reports highlighted various measures taken and gave an overview of the progress made, constraints and challenges encountered in promoting the status of women in line with the provisions of the Convention from July 2006 to December 2014. By the time of presentation of the 8th report, the government was reported to have taken a variety of participatory and inclusive measures to address constitutional and legal stereotypes and discrimination against women. One of such critical steps is towards affirmative action in politics, a special measure taken to ensure equality between women and men.

The government had reviewed the 1999 Constitution to conform to international best practices and standards. Section 40 of the constitution is particularly important in this case as it guarantees the right of every citizen to freely associate and assemble, especially the right to belong to any political party, trade union or any other association. The constitution also confers the right to register and to vote for the purpose of election on every citizen that has attained the age of 18 years regardless of sex.

A key policy document that supports women's participation in political and public life is the National Gender Policy (NGP). Adopted for the 2007 general elections, the policy was produced under the Olusegun Obasanjo government by the Ministry of Women Affairs and Social Development as a development strategy towards the reduction of poverty levels among women and men, as well as improving health and living standards and enhancing efficiency of public investments. A strategic framework for the implementation of the NGP was later developed and adopted in 2008, during the Musa Yar'Adua administration. The NGP which replaced the National Policy on Women, gave way to a range of initiatives meant to address gender inequalities and eliminate barriers such as discrimination. One of the document's priority targets included politics and decision making, with the policy goal to: achieve gender equity in political participation and representation, and to draw up mechanisms for the empowerment of women in politics (Federal Government of Nigeria, 2006).

The first objective of the policy is aimed at increasing the level of women participation in politics. Strategies for implementation included achieving a minimum threshold of representation for women in order to promote equal opportunity for women and men in all areas of political life:

Sensitization of women to political participation - Create an enabling environment for women to participate in politics - Provide financial incentives and other waivers to encourage women to participate in politics - Economic empowerment and adequate education of women for political participation - Community mobilisation through women organisations - Eradicate all discriminatory policies against women participation in politics - Review the structure and operational guidelines of political parties, and ensure that gender is mainstreamed into the guiding principles, and operations of political parties; - That all political parties embrace affirmative action to progressively increase the number of women candidates for elective positions, and 
ensure at least $30 \%$ representation of women in the 2007 national elections, and a progression to $50 \%$ representation by the year 2011 - Until gender parity is achieved, women political candidates to be supported financially by special funds put aside by the government for this. - Project respectable female politicians as role models. (Federal Government of Nigeria, 2006)

Objective 2, of the policy focused on increasing the number of women in elective positions and decision-making process by:

\begin{abstract}
Implementation of affirmative action in politics $(30 \%$ of political posts to be reserved for women - Mainstream gender into party politics at all levels - federal, state, and LGAs - Reform the existing traditional structures, which exclude women from participating in decision-making, and make them amenable to equality principles • Sensitisation of the traditional councils to the rights of women to participate in politics - Conscientisation of electorates on democratic principles and practices.

(Federal Government of Nigeria, 2006)
\end{abstract}

Part of the objective include adopting special measures, quotas and mechanisms for achieving minimum critical threshold of women in political offices, party organs and public life by pursuing 35 per cent affirmative action in favour of women to bridge gender gap in political representation in both elective and appointive posts by 2015 (Nigerian CEDAW NGO coalition, 2008). Moreover, as a measure to increase women's political participation during the 2007 general elections, the government convened meetings with women opinion leaders and the Independent National Election Commission (INEC) to map out strategies towards engaging women for the upcoming general elections.

Other initiatives that came out of the NGP was the Zonal Women Political Empowerment Offices, the office was established to support NGOs that employed and worked with women's groups that mobilised women towards political participation for the 2007 general elections. Female aspirants and candidates were essentially given capacity building technical support. This effort substantially contributed to the increase in the number of women in the National Assembly from 25 (5.4\%) in 2003 to 34 (7.7\%) in 2007 and 32 (6.8\%) in 2011 (Federal Republic of Nigeria, 2015).

Each Nigerian administration was known for particular strides made to improve the status of women in politics. The Obasanjo administration played a key role in the adoption of international standards on gender and human rights, whereas both the Yar'Adua and Jonathan administrations focused on implementing such policies. Goodluck Jonathan's much touted 35 per cent representation of women in government saw a record number (by the country's standards) of women taking up leading positions within his cabinet (See table 3 ). Despite this number, the percentage was still below the gender quota Nigeria had out its support behind at the international level and also set as a core target within the NGP. The NGP provides several frameworks and tools to facilitate targets and benchmarking for assessing results as well as a five yearly review for achievement of set targets. The process of mainstreaming gender related issues in government polices resulted in the efforts at implementing a 35 per cent representation of women at all levels of decision making, otherwise known as 35 per cent affirmative action. However, the reality presents a different picture. The NGP has been criticised as being a purely academic exercise because the government has been slow to affirm the provisions, nor has the NGP been used to develop and implement a viable action plan Nigerian CEDAW NGO coalition, 2008). Many civil society groups and NGOs, monitoring the government's actions are pessimistic that the affirmative action provision will ever be implemented primarily because of the absence of a viable action plan. Moreover, without constitutional support, enforcement would be almost impossible.

Although CEDAW continues to be implemented by the government as it relates to issues affecting Nigerian women, the CEDAW has still not been made a part of Nigeria law as a whole. Over the years, the government has taken legislative action and domesticated parts of CEDAW and other treaties to improve the participation of women in political and public life through the adoption of the Gender Equality Opportunity Bill, the Gender Mainstreaming Bill, the Affirmative Action Bill and the CEDAW Bill. The main criticism has been that despite the governments progress, reports still show that 48.78 per cent of the national population of Nigeria, still remain under represented in Nigeria's political life and decision-making processes.

\title{
3. Putting participation into context
}

The situation of women's level of participation and representation in politics and public service in Nigeria signifies that the Nigerian government is not carrying out its obligations as required by CEDAW. The poor conditions at different levels has been attributed mainly to the non-domestication of CEDAW. Lack of financial capacity of women and the culture of violence that surrounds Nigerian politics have also been the source of inequality and discrimination in the political sphere. 


\subsection{Political parties}

Conditions within political parties in respect of the intra-party practices and democratic processes are of significant importance in the achievement of gender equality in politics and decision making. Political parties have been described as the 'gatekeepers' to positions of power and decision making primarily because it is through this institution that public figures are not only elected, but also engage with the government and the citizens. The outcomes of internal processes such as the identification, selection and nomination of candidates for internal leadership and public decision making positions, go on to affect the wider political environment. Simply put, if the internal process for selecting and electing national candidate is unfair, it speaks to the whole credibility of that democratic process.

In relation to political parties in particular, the voice of women in decision-making remains insufficient, and, in some cases, is non-existent. Based on the findings of a two-year project implemented by International IDEA, aimed at analysing the commitments of political parties to gender equality in 33 countries in Africa, one of the key findings was that, although political parties' constitutions and manifestos contain general gender equality commitments, their utility is limited by the lack of concrete measures to ensure that commitments are translated into effective actions and outcomes (International IDEA, 2014).

Leading up to the 2007 general elections, a few of the political parties had taken measures to increase the participation of women in politics. Female aspirants were given a waiver for nomination forms fees. As their male counterpart were made to pay the usually high nomination form fees, many saw this as a step backward for gender equity. The argument suggested that rather than creating further inequalities, the cost of the nomination form should be significantly reduced to create an even playing field for both genders, so the competition would not be on who could afford the form, but on what the nominees could deliver. By the time party nomination and consent forms were made available for the 2015 general elections, concerns on the cost of party nomination forms were still present. At the time the current president was paying for his expression of interest and nomination forms to contest the presidential elections, he regretted that he could not influence the party to reduce the price of the forms to enable the disabled, women and other disadvantaged groups who may want to participate in the process.

It's a pity I couldn't influence this amount to be put down as in the case of ladies and the disable that intend to participate.... N27 million is a big sum, thankfully I have personal relationship with the manager of my bank in Kaduna and I told him that very soon the forms are coming, so, whether I am on red, or green or even black please honour it otherwise I may lose the nomination (The global village extra, 2014).

Similarly, during his interview with journalists, an aspirant for the Benue House of Assembly, Mr Joseph Boko, called on his party to reduce the cost of its nomination forms so as not to block quality aspirants from contesting. Most political parties either waived or subsidised the cost of nomination forms in support of female aspirants because it was believed that most women could not afford the huge cost to obtain forms. This effort did not help in increasing women's political participation, rather, party leaders used this measure to undermine women who would have made use of this assistance by withdrawing their nomination as the party's candidate/delegate in favour of those who were able to pay huge amounts for the nomination form Nigerian CEDAW NGO coalition, 2008). The chairperson of Women in Politics Forum (WiP), Barrister Ebere Ifendu, had noted that,

Because there is no internal democracy in political parties, women were not able to come out as candidates. Secondly, because of the tokenism of the free forms that the political parties give women, when it comes to consensus, it is the woman that is often asked to step down. They will rather consider someone who paid for forms, in that they will scheme us out again. It is like giving you something with the right hand and taking it back with the left hand. (Akor, 2015)

Some arguments even go as far as to say that in most political parties, women politicians were mere praise singers, mobilisers and party supporters, and only a few of them are party delegates. In 2011 , an unprecedented number of women (500) won their parties' nominations as candidates for the state and federal legislative houses (Federal Republic of Nigeria, 2015). The government reports that the results of local government elections in at least 20 states show a surge in women's entry, marking a new phenomenon in female participation. As a result, more progress was expected in 2015 as the government vowed to continue its efforts to update existing institutional mechanisms and to build new ones (Federal Republic of Nigeria, 2015). However, by the time the 2015 elections were completed, parties were being accused of both deliberately or by error of omission, not adhering to the principle of gender parity in political representation (Quadri, N.D). Only one party out of the 30 registered political parties put forward a female candidate for the presidential elections.

It is because the electoral act has no provision for legislated quotas for political parties, parties are free to adopt or not to adopt a gender quota. Unless stated in the party constitution, which the electoral act requires parties to have, parties are not required to ensure a certain percentage of candidates or legislators are female 
party members. In the past, only the two major political parties, then Action Congress of Nigeria (ACN) and the People's Democratic Party (PDP), had outlined measures that aim to address the underrepresentation of and discrimination against their female party members, even though these measures were viewed as weak and insufficient. ACN's 2009 Constitution stipulated that the Board of Trustees shall consist of one member from each state of the federation in addition to two nominees from each of the six geopolitical zones, provided that one of the two nominees from each geopolitical zone was a woman. The Constitution of the PDP provides that in the process of nominating candidates for party primary elections at the ward level, one in every three elected candidates must be a woman. The candidates will themselves be elected by direct primaries in which all cardcarrying party members at ward level shall participate. Other parties, unless specifically set up to focus on getting more women in politics have at best a quota system of roughly 30 per cent affirmative action or an informal policy that very male candidate should select a female running mate. Most times, these actions are seen as mere political tactics to win more votes and not necessarily to improve women's representation in decision making positions. The idea of seeing women playing the number two role in the home has transcended into political life where women are rightly or wrongly encouraged to aim for the number two positions to support their male counterparts. Many have voiced concerns about this perception. During the 2015 elections, more women candidates ran alongside their male governorship candidates as deputy governors.

Table 1. Candidates for 2015 governorship elections, aspirants that ran alongside women

\begin{tabular}{llll} 
& & & Sex \\
\hline Governor & $\mathrm{M}$ & $\mathrm{F}$ & $\mathrm{F}$ \\
Deputy Governor & $\mathrm{F}$ & $\mathrm{M}$ & $\mathrm{F}$ \\
Total couples & 56 & 19 & 6 \\
\hline
\end{tabular}

Source: INEC Candidates for governorship election 2015

Table 1. shows that there were more female deputy governor aspirants that ran alongside their male governor aspirants than female governor aspirants that ran alongside their male deputy governor aspirant. It also shows that there were fewer governorship aspirant couples that consisted of both female governor and deputy governor aspirants.

There is no doubt that increasing the awareness and understanding of gender issues within political parties as institutions that can support democracy building remains a challenge (Kandawasvika-Nhundu, 2013). It is thus important that strategies for gender equality and women's political empowerment be put into practice within political parties in order to create an enabling environment for the meaningful and influential participation of women.

\subsection{Public service}

December 2015 data gathered from the Inter-Parliamentary Union (IPU) shows that the global average of women in Parliament across the world was 22.4 per cent. Europe led the ranking with an average representation of 25.2 per cent, followed by Sub-saharan Africa with 22.6 per cent, Asia with 19 per cent and the Arab states with 18 per cent (Gender in Politics , 2016). The Nordic countries alone surpassed the global figure at 41.5 per cent, whereas 42 countries in the world have 30 per cent women MPs in their Parliament, five of those countries are in Africa (Gender in Politics , 2016). Out of the three countries in the world that have absolute gender parity in the parliament, one is from Sub Saharan (Rwanda) with 63 per cent, which is interestingly more than that of the other two countries within that group Bolivia (53 per cent) and Andorra (50 per cent) (Gender in Politics , 2016). February 2016, figures show a slight increase in the world average, with 22.6 per cent of women in both house of parliament are women. On the basis of information provided, the Nordic countries topped the regional average with 41.1 per cent and Sub-Saharan Africa came in fifth with out of eight regions with 23.3 per cent (Gender in Politics , 2016).

According to these figures, Sub-Saharan Africa is faring relatively well in gender parity, at the parliamentary level. As of 2014, at least 16 African countries have passed parity laws. For instance, Rwanda reserves a percentage of parliamentary seats for women, while other countries like Senegal have set gender quotas for women on candidate lists. In other instances, like in Senegal, the percentage of women in the Senegalese legislature doubled in 2012 due a change in the law. With the successful election of Catherine Samba-Panza as the president of the Central African Republic, Africa can now boast of having three heads of state. Liberian President Ellen Johnson Sirleaf, was the first to set the pace in 2005 as the country emerged from 13 years of civil war. Joyce Banda won the vote in Malawi in 2012 after the sudden death of the president. Each of these women has taken office amid crisis with the hope of leading their countries during its transition period. Mali has also seen its first female presidential candidates.

As the glass ceiling is being shattered across Africa, it is hoped that similar occurrence will take place in Nigeria. With a considerably large female population active in national politics the hope is that more women will take up similar positions, with the absence of crisis to spur such events. However, figures and expert analysis show that Nigeria's position in the world from 1999 to date has been comparatively behind. Although gradual 
progress is being made, women's participation in decision-making in elective/appointed positions, particularly in the Upper and Lower Houses of the National Assembly, and at the local government level is happening at a slow pace. December 2015 figures ranked Nigeria $134^{\text {th }}$ out of 190 countries classified by descending order of the percentage of women in the lower or single House (Inter-Parliamentary Union, 2015). As at February 2016, that ranking fell to $175^{\text {th }}$ out of 190 .

Out of the 360 members elected in 2015, into the House of Representatives, only 12 were women from: Bende constituency (PDP) and Isuikwuato/Umunneochi constituency (PDP) in Abia state; Aguta constituency (PDP) in Anambra; Ogbia constituency (PDP) in Bayelsa; Gwoza/Damboa/Chibok constituency (APC) in Borno; Uvwie/Okpe/Sapele constituency (PDP) in Dleta; Uzo-Uwani/ Igbo Etiti constituency (PDP) in Enugu; Kaltungo/Shongom constituency (PDP) and Dukku/Nafada constituency (APC) in Gombe; Ajeromi/Ifelodun I constituency (PDP) in Lagos; Ayedaade/Irewole/Isokan constituency (APC) in Osun; and Gulani/Gujbadamaturu/Tarmuwa constituency (APC) in Yobe. This means that only 3.3 per cent of the members currently elected in to the House of Representatives are women. Is this a true demographic representation of women in the country?

Representation of the people in government is a central concept of democracy. With Nigeria being revered as the largest democratic nation in Africa, one must constantly scrutinize the level of representation that the Nigerian population is accepting. According to John Adams, one of the principle writers of the American constitution (of which Nigeria's constitution is based on) a country's legislature should be a miniature portrait of the population.

Table 2. Women Elected to Public Office in Nigeria 1999-2011

\begin{tabular}{|c|c|c|c|c|c|c|c|c|c|c|c|c|}
\hline & & 1999 & & & 2003 & & & 2007 & & & 2011 & \\
\hline Office & $\begin{array}{r}\text { Seats } \\
\text { available }\end{array}$ & Women & $\begin{array}{r}\% \\
\text { age }\end{array}$ & $\begin{array}{r}\text { Seats } \\
\text { available }\end{array}$ & Women & $\begin{array}{r}\% \\
\text { age }\end{array}$ & $\begin{array}{r}\text { Seats } \\
\text { available }\end{array}$ & Women & $\begin{array}{r}\% \\
\text { age }\end{array}$ & $\begin{array}{r}\text { Seats } \\
\text { available }\end{array}$ & Women & $\begin{array}{r}\% \\
\text { age }\end{array}$ \\
\hline President & 1 & 0 & & & 0 & & & 0 & & & 0 & \\
\hline Senate & 109 & 3 & 2.8 & 109 & 4 & 3.7 & 109 & 9 & 8.3 & 109 & 8 & 7.3 \\
\hline $\begin{array}{l}\text { House of } \\
\text { Representatives }\end{array}$ & 360 & 7 & 1.9 & 360 & 21 & 5.8 & 360 & 27 & 6.9 & 360 & 24 & 6.7 \\
\hline Governor & 36 & 0 & & 36 & 0 & & 36 & 0 & & 36 & 0 & \\
\hline $\begin{array}{l}\text { State House } \\
\text { Assembly } \\
\text { (SHA) }\end{array}$ & 990 & 24 & 2.4 & 990 & 40 & 3.9 & 990 & 57 & 5.8 & 990 & 69 & 7 \\
\hline $\begin{array}{l}\text { SHA } \\
\text { Committee } \\
\text { Chairpersons }\end{array}$ & 829 & 18 & 2.2 & 881 & 32 & 3.6 & 887 & 52 & 5.9 & 887 & NA & \\
\hline $\begin{array}{l}\text { LGA } \\
\text { Chairpersons }\end{array}$ & 710 & 13 & 1.8 & 774 & 15 & 1.9 & 740 & 27 & 3.6 & 740 & & \\
\hline Councillors & 6368 & 69 & 1.1 & 6368 & 267 & 4.2 & 6368 & 235 & 3.7 & 6368 & NA & \\
\hline
\end{tabular}

Table 2. shows an increase in the percentage of elected female House of Representatives members from 1.9 per cent in 1999 , to 5.8 per cent, to 6.9 per cent, and to 6.7 per cent in 2011 . However, with only 3.3 per cent representation in 2015 , there is a sharp decrease in the number of women in the second chamber. INEC figures for elected Senate members shows that only 6 women were elected as Senators in 2015. According to Table 2 and INEC's published spread sheet, there was a 1.8 per cent fall in the number of women elected into the Senate. This idea of demographic representation has recently led to a call for more equal representation of women and minorities, for demographic representation for all. Demographic representation is arguably one of the more controversial forms of representation because it is the kind of representation where the characteristics (demographics) of the legislators proportionally reflect those of the population being represented. Almost half of Nigeria's population is female. There are more females than males in all age groups between 20 and 35 years and there are more women and girls with basic education. Despite these figures, the proportion of representation at the National Assembly is less than a quarter of what it should be. Only a representative familiar to the constituent can understand the concerns of that constituency. It is for this reason that policies related to women cannot be adequately addressed unless women are more involved in policy making.

\subsection{Appointments}

Although there has been progress in the appointment of women into ministerial positions, (with exception of the Jonathan administration) the percentage representation has been low as presented in Table 3 . Under the current administration, representation of women in appointive positions can be seen below (Table 3.1.). 
Table 3. Federal appointments of female representatives under consecutive administrations ${ }^{1}$

\begin{tabular}{lrrrr}
\hline & $\begin{array}{r}\text { Number of } \\
\text { Positions }\end{array}$ & $\begin{array}{r}\text { Olusegun Obasanjo } \\
\text { Administration }\end{array}$ & $\begin{array}{r}\text { Musa Yar'Adua } \\
\text { Administration }\end{array}$ & $\begin{array}{r}\text { Goodluck } \\
\text { Jonathan } \\
\text { Administration }\end{array}$ \\
\hline Cabinet Ministers & 42 & 7 & 7 & 13 \\
$\%$ Representation & 100 & 16.66 & 16.66 & 30.95 \\
$\begin{array}{l}\text { Permanent } \\
\text { Secretaries }\end{array}$ & 43 & 8 & 9 & 11 \\
$\%$ Representation & 100 & 18.60 & 20.93 & 25.58 \\
\hline Source: Ochanja et al $(2013)$ & & & &
\end{tabular}

Table 3.1 Federal appointments of female representatives from 2014-2016 under the current administration

\begin{tabular}{llll}
\hline$S / N$ & Number of positions & $\begin{array}{l}\text { Muhammadu } \\
\text { Administration }\end{array}$ & Buhari \\
\hline $\begin{array}{l}\text { Cabinet ministers } \\
\text { \% Representation }\end{array}$ & 36 & 5 \\
$\begin{array}{l}\text { Permanent secretaries } \\
\text { \% Representation }\end{array}$ & 100 & 13.88 \\
\hline
\end{tabular}

Source: Embassy of the Federal Republic of Nigeria, Washington DC and Federal Civil Service official website.

Further representation of women in international agencies and in the Foreign Service is equally very poor. In 2006, out of 87 ambassadors appointed to different missions, only seven were women, representing only 8 per of the total number Nigerian CEDAW NGO coalition, 2008). . Of the seven, two were career Ambassadors and five were non-career Ambassadors. Of the 593 Diplomatic Staff appointed to the Foreign Service, 63 were women representing just over 10 per cent. Table 4. shows an unchanging ratio in the appointment of Ambassadors. To date, there have been no special measures by the government to recruit women into the Foreign Service or international organisations. One of the reasons for this is the indigeneity principle which has been working against married women seeking public appointments. Part of the requirement for public appointments is to submit a State of Origin certificate. Women married to men from a different state of origin often have difficulty in getting public appointments. This is because a married woman is deemed to acquire her husband's state of origin. The irony is that many married women are also not recognised for appointments in their 'new' state of origin and cannot claim their 'old'.

Table 4. Number of Ambassadors in Service by Gender, 2006 - 2014

\begin{tabular}{lrrrrrr}
\hline Year & \multicolumn{2}{c}{2006} & \multicolumn{2}{c}{$2007-2008$} & Male & Female \\
\hline & Male & Female & Male & Female & Mal4 \\
Number & 80 & 7 & 64 & 7 & 82 & 11 \\
$\%$ & 91.96 & 8.04 & 90.1 & 9.9 & 88.2 & 11.8 \\
Total & & $87(100 \%)$ & & $71(100 \%)$ & & $93(100 \%)$ \\
\hline
\end{tabular}

Source: Ministry of Foreign Affairs, Abuja 2014, Daily Champion Newspaper, September 2007; The Punch Newspaper, Jamuary 2014

However, between 2007 and 2014, representation at the international level, particularly appointments into top Foreign Service positions was diverse. Generally known as a male dominated profession, appointments into the top Foreign Service position were based on experience. As a result, the number of women representing the country in foreign missions and international agencies both on appointment and on personal merit has increased. The government has also appointed women in the fore-front of its foreign policy negotiations, diplomacy and economic development, especially in recognition of the Nation's role in Africa as a driver of peace, stability and centre of commerce and growth. Since 2008 Professor Joy Ogwu has been the Permanent Representative of Nigeria to the United Nations. She is the second woman to hold a predominately male-appointed post and is

\footnotetext{
${ }^{1}$ Based on the information on the Federal Civil Service website, the total number of position for cabinet ministers under the Jonathan administration was 41 , therefore the \% representation would be $31.7 \%$. See http://services.gov.ng/the-federal-executive-council

${ }^{2}$ Information not available on official websites as of March 6, 2016
} 
currently also the president of the Executive Board of the UN Women Entity for Gender Equality and the Empowerment of Women. Within international organisations, the government reports that it has encouraged women to apply and secure jobs as heads of missions, top notch advisors and judges within and outside the shores of Nigeria (Federal Republic of Nigeria, 2015). The Federal Executive Council of Nigeria approved $\$ 500,000$ USD for UN Women core funding, demonstrating its firm support of UN efforts in the field of gender equality and the empowerment of women (UN Women, 2011).

Table 5. Number of Officers in Foreign Service by Gender, 2014

\begin{tabular}{llcccr}
\hline S/N & Cadre & Male & Percentage & Female & Percentage \\
\hline i. & Top Management & 94 & $90.4 \%$ & 10 & $9.6 \%$ \\
ii. & Middle & & & & \\
& Management & 210 & $72.7 \%$ & 79 & $27.3 \%$ \\
iii. & Lower & & & & \\
& Management & 230 & $58.1 \%$ & 166 & $41.9 \%$ \\
& Total & 534 & $67.7 \%$ & 255 & $32.3 \%$ \\
\hline
\end{tabular}

Source: Ministry of Foreign Affairs, Abuja 2014

Appointments within international organisations are surprisingly similar. UNESCO for instance reserves, one major position to be occupied by a female representative. Yet despite such a small slot, it has been reported that this slot is usually given to male representatives. Societal norms seem to have penetrated the recruitment policy at the Foreign Service further exacerbating discrimination against women in the Foreign Service. For instance, it was reported that attitudes towards unmarried woman or divorcees were different than to married women.

\section{Mainstreaming Women's Interest}

Gender mainstreaming was established as a major global strategy for the promotion of gender equality in the Beijing Platform for Action. It is essentially about changing attitudes and relationships at many levels, including making women's as well as men's interests integral to the design, implementation, monitoring and evaluation of policies and programmes in all political, economic and societal spheres. A number of points raised below and throughout the paper are essentially in connection with breaking the cycle of discrimination, and promoting greater inclusion and participation among women. However, the first recommendation is the need to include men. Any solution that sees men as the problem rather than part of the solution is likely to create resistance to change.

\subsection{Role of international Agencies and National Civil Society Groups}

Advocacy efforts for the rights of women should adopt a broad approach to the strategy for political reform, focusing not only on provisions of direct import to the interests of women but also on a robust human rights framework, an independent electoral commission, accountable government and transparent political parties in general.

Agencies need to continue to push for an institutionalized NGP machinery. This produces a single, direct route to government cooperation with agents, such as women's movements, who traditionally act outside the state. A strong women's movement acting in conjunction with an effective women's agency are in a better position to predict the extent of the government commitment to balancing the gender gap and reducing discrimination in politics.

There is a need not to over-romanticize participation as is the trend of international agencies in order to galvanise support behind a certain cause. Agencies must be realistic in their expectations of government, giving further support for greater research to be conducted into the area of female participation in politics.

\subsection{Role of Federal Government}

Priority attention should be given to following up the part of the Beijing Platform for Action concerning women's participation in politics and the decision-making process. This action can be carried out in parallel with the follow-up to the Plan of Action to correct present imbalances in the participation of men and women in political life and corresponds to the commitments made in the Beijing Parliamentary Declaration by those government representatives who took part in the Beijing Conference.

It is important to design and implement normative and gender-sensitive constitutional frameworks (as contemplated by Sections 14(3) (4) of the Constitution) in order to move towards equal gender representation and participation in political processes and institutions. It is thus essential to ensure that women participants in 
this process have positions of authority in the leadership of the institution and of sub-committees.

There is a need to focus on training women through innovative programs that strengthen women's political skills, emphasise how women are impacted by public policy, and improve the perception of women in political life.

There is also a need to include gender perspectives in every policy program. This dual approach will strengthen the government's ability to build women's skills and organise women across ethnic and political lines, as well as create the opportunity for women from diverse backgrounds to converge around shared goals to solve problems in ways that contribute to the development and well-being of their communities.

There is also a need for special measures to be taken by the government to recruit women into the Foreign Service or international organisations.

There is the need to develop a project focused on the collection of stories of women's experience in politics, a story that mere numbers cannot tell. These experiences will go hand in hand with data collected to build a more personalized account of the conditions women are faced with in public life.

There is a need for greater thought about effective participation for gender equality. This includes understanding that men, as well as women, should be included in any agenda for change as well; interrogating the term 'women's groups' to understand that they are not monolithic, and that they may have hierarchies of identity which compete with objection for equal representation.

\subsection{Role of political parties}

There is a need for political parties to increase the awareness and understanding of gender issues within politics. Among other things, clear and coherent gender-sensitive policies are needed. It is thus important that strategies for gender equality and women's political empowerment be put into practice within political parties in order to create an enabling environment for the meaningful and influential participation of women

Parties need to take active steps in terms of adopting a gender quota in their party constitutions. There is also a need to hold a national political party workshop with INEC where imputing a gender quota in the electoral act will be discussed. Such measures will ensure that a gender quota system is properly implemented. In Libya and Tunisia, quota systems were either used in a minority of seats (Libya) or poorly implemented (Tunisia), resulting in less than the 50 per cent representation anticipated. The lesson here is that identifying mechanisms that facilitate women's equal representation requires an examination of the efficacy of deploying particular quota percentages in the cultural and political contexts under consideration. It also requires electoral provisions electoral laws that are conducive to the equal representation of women. Moreover, electoral management bodies must properly implement and monitor these legal requirements.

A change in the method of voting can greatly improve women participation. Certain options deployed to elect party officials or candidate to represent the party such as zipper or zebra candidate lists can increase women's representation. Quotas have been one of the key approaches used to increase women's representation, but the zipper system is increasingly recognized as an important mechanism to raise gender representation (International IDEA, 2014). Under this system, up to 50 per cent (International IDEA, 2014) representation of women is guaranteed, only if there is genuine political will to fully implement it in ways that result in parity. Candidates on election lists are listed alternately on the basis of gender. Thus, if the first candidate on the list is male, the second must be female.

\section{Conclusion}

One of the most persistent democratic concerns to policy makers in Nigeria and across the developing world is women's lack of influence in politics. Despite their numbers across and within countries, women remain underrepresented; they face structural barriers and are further marginalised by the existence of capacity gap. However, as the pool of qualified women grows as more girls get to stay in school, girls and young women are getting the much needed role models to encourage greater female activism in Nigerian politics.

Africa alone presents remarkable as well as disappointing figures in participation and representation. Prominent Senegalese politician and Presidential Adviser Penda Mbow says true equality requires societal change.

Parity laws may be one tool but they are not enough. We also need to fix what goes on inside political parties and let capable, promising women emerge naturally so that when they are promoted, no one can say they got special treatment.(Look, 2014)

A key challenge facing women in Nigeria therefore is how to secure a constructive political role against an environment which seeks to exclude them from public life. Women's access to politics highlights both the challenges they face in gaining access to the political domain and the strategies that can be used to overcome them. While increasing the number of women is a priority concern, it is equally important that once in decision making position women commit themselves to democratic practises and respect the right of all citizens to participate in governance. 
As observed, Women's equal participation in decision-making is not only a demand for simple justice or democracy, it can also be seen as a necessary condition for women's interests to be taken into account. Without the active participation of women and the incorporation of women's perspectives at all levels of decision-making, the goals of equality, development and peace cannot be achieved (The United Nations Fourth Conference on Women, 1995). While the Federal Government has embraced the various instruments aimed at gender equality and equity in political life, the current trend indicates that urgent action is required to prevent a relapse into a situation in which the voices of women in Nigeria are muffled, with dire consequences for their welfare and the society.

\section{References}

Akor, O. (2015, April 24). How Women Performed in the 2015 General Elections. Daily Trust, p. http://allafrica.com/stories/201504241186.html.

Awofeso, O., \& Odeyemi, T. I. (2014). Gender and political participation in Nigeria: a cultural perspective . Journal Research in Peace, Gender and Development, 104-110.

Bari, F. (2005). Women's Political Participation: Issues and Challenges. Bangkok: United Nations Division for the Advancement of Women (DAW).

Federal Government of Nigeria. (2006). National Gender Policy. Abuja: FRN.

Federal Republic of Nigeria. (2015). Consideration of reports submitted by States parties under article 18 of the Convention: Combined seventh and eighth periodic report of States parties due in 2014. Abuja: CEDAW/FRN.

Gender in Politics . (2016). Retrieved from http://genderinpolitics.org/

Gray MM, K. M. (2006). Women and globalization: a study of 180 countries, 1975-2000. Int. Organ, $293-233$.

International IDEA. (2014). Marginalised groups and constitutional building. Strömsborg: International Institute for Democracy and Electoral Assistance .

Inter-Parliamentary Union. (2015, December 1). Women in national parliaments, as at 1 Decembr 2015. Retrieved from Inter-Parliamentary Union: http://www.ipu.org/wmn-e/classif.htm

Kandawasvika-Nhundu, R. (2013). Political Parties in Africa through a Gender Lens. Strömsborg: International Institute for Democracy and Electoral Assistance .

Keck ME, S. K. (1998). Activists Beyond Borders: Advocacy Networks in International Politics. New York: Cornell University Press.

Kenworthy L, M. M. (1999). Gender inequality in political representation: a worldwide comparative analysis. Soc. Forces, 235-268.

Look, A. (2014, February 8). Women on the Rise in African Politics. Retrieved from VOA: http://www.voanews.com/content/women-on-the-rise-in-african-politics/1847360.html

Nigerian CEDAW NGO coalition. (2008). The Nigerian NGO CEDAW Coalition shadow reoprt. The Nigerian CEDAW NGO coalition

Paxton, P. (1997). Women in national legislatures: a cross-national analysis. Soc. Sci. Res., 442-464.

Paxton, P., Kunovich, S., \& Hughes, M. M. (2007). Gender in Politics. The annual review of sociology, 263-284.

Quadri, M. O. (n.d.). Women and Political Participation in the 2015 General Elections: fault lines and mainstreaming exclusion. Lagos: Department of Political Science University of Lagos .

The global village extra. (2014, October 14). 2015: Buhari Laments High Cost Of N27.5m APC Nomination Form, After Paying. Retrieved from The global village extra: http://globalvillageextra.com/2015-buharilaments-high-cost-of-n27-5m-apc-nomination-form-after-paying/

The Nigerian CEDAW NGO coalition. (2008). The Nigerian NGO CEDAW Coalition shadow reoprt. The Nigerian CEDAW NGO coalition.

The United Nations Fourth Conference on Women. (1995). Action for Equality, Development and Peace. Beijing, China: UN Women.

Tsododo, V. (2014). Gender Equality and the Participation of Women in Public Office in Swaziland. Ghana: Afrobarometer.

UN Women. (n.d.). Women's leadership and political participation. New York: UN Women.

UN Women. (2011, May 4). Federal Executive Council of Nigeria Approves \$500,000 for UN Women. Retrieved from UN Women: http://unwomenwestafrica.blog.com/about-un-women-west-africa-subregional-office/nigeria-2/

UN Women. (2016). Women's leadership and political participation. Retrieved from UN Women: Women's leadership and political participation 